\title{
Promising new borehole liquids for ice-core drilling on the East Antarctic high plateau
}

\author{
Simon G. SHELDON, Trevor J. POPP, Steffen B. HANSEN, Jørgen P. STEFFENSEN \\ Centre for Ice and Climate, Niels Bohr Institute, University of Copenhagen, Denmark \\ E-mail: sheldon@nbi.ku.dk
}

\begin{abstract}
A drill liquid is essential for the purpose of recovering good-quality scientifically useful ice cores at intermediate to deep depths, i.e. $>\sim 100 \mathrm{~m}$. The pressure produced by the liquid helps to eliminate the detrimental effects of the abrupt release of isostatic pressure in the ice during the drilling process, prevents consequential fractures within the ice core, and is essential to produce an even distribution of hydrostatic pressure to balance the ice isostatic pressure and so minimize borehole deformation. To perform these tasks, while minimizing risks to health and the environment, the liquid needs to exhibit specific physical, chemical and biological characteristics. Here we report on two promising candidate drill liquids, ESTISOL ${ }^{\mathrm{TM}} 140$ and ESTISOL $^{\mathrm{M}}$ 165, for use in the extreme conditions found within the ice sheets of Greenland and Antarctica, where the temperature can range from close to $0^{\circ} \mathrm{C}$ to below $-57^{\circ} \mathrm{C}$ and pressures can exceed $40 \mathrm{MPa}$. From both the manufacturer's data and our laboratory tests and observations we report on the physical, chemical and biological characteristics that both liquids exhibit. We also report on how one of the candidates was field-tested on the Greenland ice sheet and the East Antarctic high plateau.
\end{abstract}

KEYWORDS: glaciological instruments and methods, ice coring, ice engineering

\section{INTRODUCTION}

With the introduction of the UN Montréal Protocol on Substances that Deplete the Ozone Layer (1987) and following the Accelerated Phase-out of Class II Controlled Substances (1993), as of 1 January 2003 the production and consumption of HCFC-141b was banned in Europe and the USA. Until this point several deep ice-core drilling operations (e.g. NorthGRIP (North Greenland Ice Core Project), EPICA (European Project for Ice Coring in Antarctica) Dome C, EPICA DML (Dronning Maud Land) and WAIS (West Antarctic Ice Sheet) Divide) had been using HCFC$141 \mathrm{~b}$ as an essential additive to fine-tune the density when mixed with de-aromatized hydrocarbon fluids (e.g. Exxsol ${ }^{\mathrm{TM}}$ D series or IsoparTM series). With the accelerated phase-out plan of hydrochlorofluorocarbon (HCFC)-141b, several teams started to investigate suitable replacement drill liquid candidates for use in future intermediate and deep ice-core drilling projects (e.g. Talalay and Gundestrup, 2002; Gerasimoff, 2003; Steffensen and others, unpublished data).

By 2011 our investigations into a replacement drill liquid included a wide variety of liquids, with notable successful use of the fatty acid esters ESTISOL ${ }^{\text {TM }} 240$ at Flade Isblink, Greenland, in 2006 and at the NEEM (North Greenland Eemian Ice Drilling) S1 core in 2011, and with a mixture of ESTISOL ${ }^{\text {TM }} 240$ and COASOL ${ }^{\text {TM }}$ at NEEM in 2009-12 (Popp and others, 2014a,b; Sheldon and others, 2014) and Roosevelt Island, West Antarctica, in 2011-13. Owing to the very rapid increase in kinematic viscosity of ESTISOL ${ }^{\mathrm{TM}}$ 240 and $\mathrm{COASOL}^{\mathrm{TM}}$ at temperatures below $-35^{\circ} \mathrm{C}$, and the subsequent extremely undesirable effects on drilling performance, this combination was considered unsuitable for use at sites on the East Antarctic high plateau.

In 2011, after being introduced by EstiChem A/S, Denmark, two new drill liquid candidates were investigated: the aliphatic synthetic ester ESTISOL ${ }^{\mathrm{TM}} 140$ and the aliphatic carboxylic acid ester ESTISOL ${ }^{\mathrm{TM}}$ 165. From the manufacturer's data specifications these two liquids appeared promising candidates.

\section{DESIRABLE CRITERIA FOR ICE-CORE DRILLING LIQUIDS FOR GREENLAND AND ANTARCTICA}

To be suitable for the purpose of recovering an ice core from $\sim 100 \mathrm{~m}$ to several thousand metres, and for supporting the borehole over subsequent decades to allow access to borehole logging instruments, several specific physical, chemical and biological attributes are required for a drill liquid, or drill liquid combination, to be successful.

\section{Density}

The essential physical characteristic of the liquid is its density. The density of the liquid, in conjunction with the liquid column height, determines the pressure exerted by the liquid on the borehole ice surface. This pressure minimizes the abrupt isostatic pressure release during the drilling process, which in turn minimizes stress-related lateral fractures produced in the ice core and thus improves ice-core quality. This drilling issue is first apparent at depths of $\sim 100 \mathrm{~m}$ where normally the drill liquid is first employed. The density is also essential to produce a balanced even distribution of pressure against the borehole wall to minimize any long-term borehole deformation.

For intermediate to deep drilling operations there are two options to match the drill liquid pressure to the ice isostatic pressure. Adjusting the liquid head height is by far the simpler and can give good pressure matching at specific depth ranges, though not necessarily the whole depth. When the liquid column height is used in combination with adjusting the density (e.g. by adjusting the mixing ratio of two liquids), the pressure matching can be set not only more precisely but over a much wider depth and temperature range.

The ice isostatic pressure is related to the ice density, which in turn is related to the ice temperature and depth and 


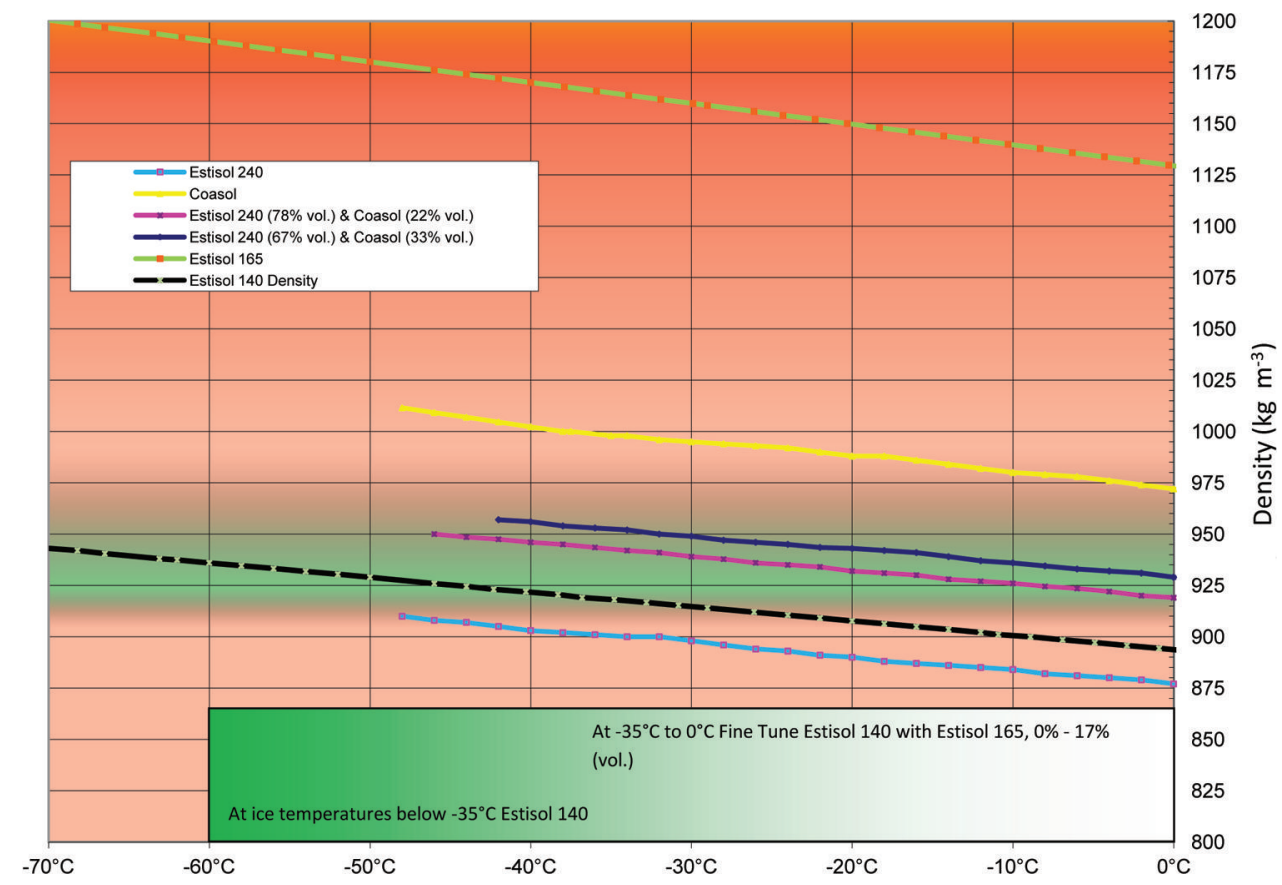

Fig. 1. Density temperature characteristics: comparison of ESTISOL ${ }^{\mathrm{TM}} 140$, ESTISOL ${ }^{\mathrm{TM}} 165$ and ESTISOL ${ }^{\mathrm{TM}}$ 240/COASOL ${ }^{\mathrm{TM}}$ mixture. For a range of temperatures from $0^{\circ} \mathrm{C}$ to $-35^{\circ} \mathrm{C}$ a mixture of ESTISOL ${ }^{\text {TM }} 140$ and ESTISOL ${ }^{\text {TM }} 165$ from $\sim 17 \%$ to $0 \%$ appears to fit into the usable density band. For temperatures from $-36^{\circ} \mathrm{C}$ to $-66^{\circ} \mathrm{C}$ pure ESTISOL ${ }^{\mathrm{TM}} 140$ appears to fit into the usable density band.

the weight of ice pressing down from above. For many sites in Greenland and the Antarctic the ice density below the firn varies from 910 to $925 \mathrm{~kg} \mathrm{~m}^{-3}$. For practical purposes a density of $\sim 920-950 \mathrm{~kg} \mathrm{~m}^{-3}$ (Gundestrup and others, 1994) over a temperature range $0^{\circ} \mathrm{C}$ to $-59^{\circ} \mathrm{C}$ is desirable, and preferably with the ability by mixing to fine-tune by $\pm 25 \mathrm{~kg} \mathrm{~m}^{-3}$.

\section{Viscosity}

The majority of drill systems used in ice-core drilling operations are wire line types. The drill is lowered down the borehole from the surface using a cable, a core is drilled, the drill and core are hoisted to the surface, the ice core is removed, the drill is cleaned and the process is repeated. This incremental drilling operation directly affects the duration of a complete drilling operation in the very expensive working environment, which is usually limited to a 1-3 month long drilling season. Thus the duration of the drill runs has a significant influence on the overall project costs. A slow operation might add 1 year or more to a project compared with a faster operation.

A significant contributor to the overall drilling operation is the time taken for the drill to descend and ascend the borehole (Vasiliev and Kudryashov, 2002) particularly when recovering ice core at greater depths such as at EPICA Dome C 2 where at $3200 \mathrm{~m} 3$ hours were required to recover $40 \mathrm{~cm}$ of ice core. The drill travel speed is related to the viscosity of the drill liquid. To allow the drill to descend and ascend quickly, a low kinematic viscosity is a desirable criterion: preferably below $25 \mathrm{~mm}^{2} \mathrm{~s}^{-1}$ (Sheldon and others, 2014) for a NEEM-configured drill, or $5 \mathrm{~mm}^{2} \mathrm{~s}^{-1}$ (Gunderstrup and others, 1994) for an ISTUK configuration.

\section{Compatibility}

For ice cores to be scientifically useful it is essential that the drill liquid has either no or very little effect on the ice or on any of the scientifically interesting chemical species contained within the core. This liquid should also be compatible with materials used in and around the drill site, the logging process and storage facilities. It should be compatible with substances or techniques used during drill emergency recovery situations and with modern borehole logging probes.

\section{Further essential properties}

Low toxicity is essential for the work environment and to minimize the environment impact

Availability, both present and in the foreseeable future

Easy logistical transport

Stability in the environmental conditions and over time

Overall costs

\section{COMPARISON OF DRILL LIQUIDS AND SUITABILITY FOR USE ON THE EAST ANTARCTIC HIGH PLATEAU}

The choice of liquids that meet the criteria for ice-core drilling is limited. Table 1 gives a comparison of several past and the two new candidates. Tables 2 and 3 show the manufacturer's data.

\section{LABORATORY OBSERVATIONS} Physical properties: density

From 2011 to 2013 we carried out several density measurements on the candidate liquids from EstiChem A/S. In the case of ESTISOL ${ }^{\mathrm{TM}}$ 140, two batches were tested giving similar results and following the published data of Talalay and others (2014) (Table 4; Fig. 1). 
Table 1. Comparison of drill liquids and relative suitability for use on the East Antarctic high plateau. Undesirable properties are indicated in boldface

\begin{tabular}{|c|c|c|c|c|c|c|}
\hline & $n$-butyl acetate* & Exxsol $^{\mathrm{TM}} \mathrm{D} 40^{\dagger}$ & ESTISOL ${ }^{\mathrm{TM}} 240^{\ddagger}$ & $\mathrm{COASOL}^{\mathrm{TM}}{ }^{\ddagger}$ & ESTISOL ${ }^{\mathrm{TM}} 140^{\ddagger}$ & ESTISOL ${ }^{\text {TM }} 165^{\ddagger}$ \\
\hline Successful ice core & $\begin{array}{c}\text { Dome } \mathrm{F} \text { and } \\
\text { GISP2 }\end{array}$ & EPICA DML & NEEM & NEEM & $\begin{array}{l}\text { ABN (Aurora } \\
\text { Basin North) }\end{array}$ & \\
\hline Drilling operation & $\begin{array}{l}\text { Antarctica and } \\
\text { Greenland }\end{array}$ & Antarctica & Greenland & Greenland & Antarctica & \\
\hline Lowest temperature $\left({ }^{\circ} \mathrm{C}\right)$ & -57 & -45 & -29 & -29 & -44 & \\
\hline Boiling point $\left({ }^{\circ} \mathrm{C}\right)$ & 126.5 & $161-198$ & $255-290$ & $274-289$ & $\sim 125$ & Unknown \\
\hline Flash point $\left({ }^{\circ} \mathrm{C}\right)$ & 22 & 40 & 136 & 131 & 75 & $>70$ \\
\hline Explosive limit (\% vol.) & $1.2-7.5$ & $0.6-7^{(1)}$ & None & $0.6-4.7$ & None & None \\
\hline $\begin{array}{l}\text { Vapour pressure }\left(25^{\circ} \mathrm{C}\right) \\
(\mathrm{kPa})\end{array}$ & 1.1 & $0.013^{(1)}$ & 0.0012 & 0.000075 & 0.031 & \\
\hline $\begin{array}{l}\text { Density }\left(20^{\circ} \mathrm{C}\right), *\left(15^{\circ} \mathrm{C}\right) \\
\left(\mathrm{kg} \mathrm{m}^{-3}\right)\end{array}$ & 880 & 771 & 863 & 960 & $860-880$ & 1070-1130 \\
\hline $\begin{array}{l}\text { Auto ignition temperature } \\
\left({ }^{\circ} \mathrm{C}\right)\end{array}$ & 425 & 260 & None & 400 & None & 482 \\
\hline Biodegradable & Yes & Yes & Yes & Yes & $\begin{array}{c}\text { Yes, } 75 \% \text { in } \\
28 \text { days according to } \\
\text { marine BODIS } \text { BOst }^{\S} \text { test }\end{array}$ & $\begin{array}{c}\text { Yes, aerobic } \\
\text { degradation: }>60 \% \\
\text { in } 28 \text { days according } \\
\text { to } \text { OECD }^{\mid l} \text { guidelines }\end{array}$ \\
\hline Firefighting equipment & $\begin{array}{l}\mathrm{CO}_{2} \text { and dry } \\
\text { chemical }\end{array}$ & $\begin{array}{c}\text { Water spray, } \mathrm{CO}_{2}, \\
\text { dry chemical }\end{array}$ & $\begin{array}{l}\text { Water spray, } \\
\mathrm{CO}_{2} \text {, foam, } \\
\text { dry chemical }\end{array}$ & $\begin{array}{l}\text { Water spray, } \\
\text { foam, } \mathrm{CO}_{2}\end{array}$ & $\begin{array}{l}\text { Water spray, } \mathrm{CO}_{2} \text {, } \\
\text { foam, dry chemical }\end{array}$ & $\begin{array}{l}\text { Water spray, } \mathrm{CO}_{2} \\
\text { foam, dry chemical }\end{array}$ \\
\hline Special protection & Safety glasses & Safety glasses & Safety glasses & Safety glasses & Safety glasses & Safety glasses \\
\hline Hazardous material & Class 3, UN 1123 & Class 3, UN 1863 & No & No & No & No \\
\hline Explosive risk & Yes & None & None & None & None & None \\
\hline $\begin{array}{l}\text { Max. workplace air levels } \\
(\mathrm{ppm})\end{array}$ & 20-150 & 197 & None & None & None & None \\
\hline Manufacturer & $\begin{array}{l}\text { Hangzhou Ruijiang } \\
\text { Chemical Co., Ltd }\end{array}$ & ExxonMobil & EstiChem A/S & DOW & EstiChem A/S & EstiChem A/S \\
\hline
\end{tabular}

*Data from the manufacturer and Gerasimoff (2003).

${ }^{+}$Data from Exxon Mobile Chemical unless ${ }^{(1)}$, then from Talalay and Gundestrup (2002).

${ }^{\ddagger}$ Data on ESTISOL ${ }^{\text {TM }}$ 140, 240, 165 and COASOL ${ }^{T M}$ are from safety tests according to EU safety 91/155/EU, article 204020, 203989, 205698 and 204872, respectively.

${ }^{\varsigma_{B O D}}$ of insoluble chemicals.

"Organization for Economic Cooperation and Development.

\section{Physical properties: viscosity}

The dynamic viscosity of the candidate drill liquids was measured for the two batches of ESTISOL ${ }^{\mathrm{TM}} 140$ and for ESTISOL ${ }^{\mathrm{TM}} 165$, and with the measurements of density the kinematic viscosity was determined. Some variation was found between the batches of ESTISOL ${ }^{\text {TM }} 140$ from 2011 and 2013, and compared with the published data of Talalay and others (2014) (Table 5; Fig. 2).

A drill liquid with low kinematic viscosity is desirable for reducing transit times and ascent system stresses. (A consequence of using a liquid with high kinematic viscosity is an increase in resistance to drill movement. During drill descent, where gravity is employed, this decreases the descent velocity. The drill ascent is achieved using cable tension exerted to overcome the force of gravity, to displace the liquid within the tight confines of the borehole and to overcome the relatively small frictional forces. Keeping the drilling parameters constant (e.g. drilling depth, borehole diameter, ascent speed, ice-core length), an increase in kinematic viscosity will require a greater cable tension to displace the liquid. This increase in tension increases stresses within the hoisted drill, the cable, the hoisting system and the power supply generators. This in turn increases component wear and fatigue, overall fuel consumption, possible component weight and associated project costs.) At NEEM we successfully used a drill liquid combination of ESTISOL ${ }^{\mathrm{TM}}$ 240 and COASOL ${ }^{\mathrm{TM}}$ with a kinematic viscosity of $25 \mathrm{~mm}^{2} \mathrm{~s}^{-1}$ for the first $50 \%$ of the drilling, which then slowly reduced to $7.5 \mathrm{~mm}^{2} \mathrm{~s}^{-1}$ at the ice-sheet base (Popp and others, 2014b). By extrapolating from these experiences we predicted for our NEEM drill configuration a reasonable working upper limit of kinematic viscosity of $\sim 35 \mathrm{~mm}^{2} \mathrm{~s}^{-1}$ (Sheldon and others, 2014). From our density and viscosity measurements, and extrapolating the $35 \mathrm{~mm}^{2} \mathrm{~s}^{-1}$ upper limit, we predict that ESTISOL $^{\mathrm{TM}} 140$ and ESTISOL ${ }^{\mathrm{TM}} 165$ will be an effective drill liquid for temperatures ranging from $0^{\circ} \mathrm{C}$ to $-54^{\circ} \mathrm{C}$.

\section{Hydrophobic properties}

The liquids were tested for hydrophobic properties, initially by mixing with water at room temperature and then with small granules of ice at $-16^{\circ} \mathrm{C},-25^{\circ} \mathrm{C}$ and $-55^{\circ} \mathrm{C}$.

At room temperature the water and candidate liquids were poured into a glass graduated cylinder and mixed thoroughly by sealing the cylinder top and shaking. The mixed components rapidly separated into two distinct layers: the water in the lower layer, the ESTISOL ${ }^{\text {MM }} 140$ in the upper 


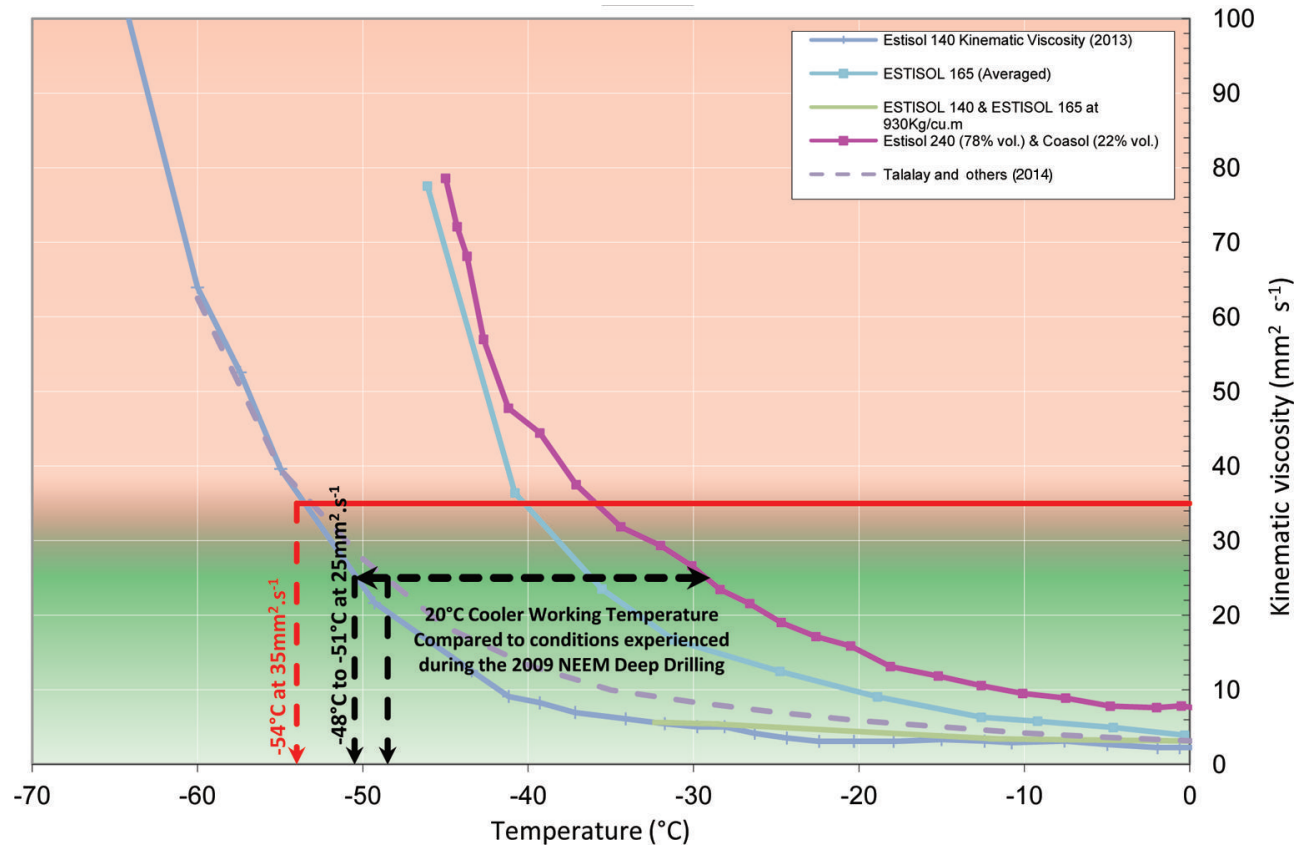

Fig. 2. Kinematic viscosity temperature characteristics: comparison of ESTISOL ${ }^{\mathrm{TM}}$ 140, ESTISOL ${ }^{\mathrm{TM}} 165$ and ESTISOL ${ }^{\mathrm{TM}}$ 240/COASOL ${ }^{\mathrm{TM}}$ mixture. For temperatures down to $-51^{\circ} \mathrm{C}$ ESTISOL ${ }^{\mathrm{TM}} 140$ appears to have a kinematic viscosity similar to or lower than what was experienced at NEEM. Using the kinematic viscosity limit of $35 \mathrm{~mm}^{2} \mathrm{~s}^{-1}$ gives a working temperature limit for ESTISOL ${ }^{\mathrm{TM}} 140$ of $-54^{\circ} \mathrm{C}$ from our measurements, similar to the results of Talalay and others (2014).

layer; and the water in the upper layer, the ESTISOL TM 165 in the lower layer. The liquids were repeatedly mixed by either stirring or shaking. On each occasion they rapidly separated into well-defined visible bands.

In a $-16^{\circ} \mathrm{C}$ freezer, granules of ice were poured into, and then mixed by vigorous shaking with, cooled ESTISOL ${ }^{\mathrm{TM}} 140$, ESTISOL TM 165 and a mixture of both containing 17\% (vol.) ESTISOL $^{\text {TM }} 165$. With pure ESTISOL ${ }^{\text {TM }} 140$ the ice granules

Table 2. Data for ESTISOL ${ }^{\mathrm{TM}}$ 140: aliphatic synthetic ester manufactured by ESTI Chem A/S, Denmark

\section{Boiling range}

Pour point, ISO 3016

SO 3104

Algal toxicity
Flash point, ISO 2719

Dynamic viscosity,

Density, DIN 51757 (4)

Danger of explosion

Biodegradability

Mobility, OECD 117

Fish toxicity

Toxicity

Sediment reworker

toxicity

Classified

$$
\begin{gathered}
195-205^{\circ} \mathrm{C} \\
75^{\circ} \mathrm{C} \\
-90^{\circ} \mathrm{C} \\
1.3 \mathrm{mPa} \text { at } 25^{\circ} \mathrm{C} \\
870 \mathrm{~kg} \mathrm{~m}^{-3} \text { at } 20^{\circ} \mathrm{C}
\end{gathered}
$$

Product does not present an explosion hazard $75 \%$ in 28 days according to marine BODIS test Log pow $=3.36$. The mobility is low. Classified as non-water miscible

Juvenile sheepshead minnow: LC50 (72 hours) $>3000 \mathrm{mg} \mathrm{L}^{-1}$; NOEC* (96 hours) $1000 \mathrm{mg} \mathrm{L}^{-1}$ according to OSPAR ${ }^{+}$guidelines

Skeletonema costatum: EC50 (72 hours) $400 \mathrm{mg} \mathrm{L}^{-1}$; NOEC* (72 hours) $319 \mathrm{mg} \mathrm{L}^{-1}$ according to OSPAR ${ }^{+}$guidelines Acartia tonsa: LC50 (48 hours) $>2203 \mathrm{mg} \mathrm{L}^{-1}$; NOEC* (48 hours) $2203 \mathrm{mg} \mathrm{L}^{-1}$ according to OSPAR $^{+}$guidelines

Corophium volutator: 10 day LC50 $5013 \mathrm{mg} \mathrm{kg}^{-1}$ according to OSPAR ${ }^{\dagger}$ guidelines No explosive risk, non-hazardous, biodegradable, low toxicity, skin irritant

\begin{tabular}{|c|c|}
\hline Boiling range & $195-205^{\circ} \mathrm{C}$ \\
\hline Flash point, ISO 2719 & $81^{\circ} \mathrm{C}$ \\
\hline Pour point, ISO 3016 & $<-30^{\circ} \mathrm{C}$ \\
\hline Dynamic viscosity, ISO 3104 & $3 \mathrm{mPas}$ at $25^{\circ} \mathrm{C}$ \\
\hline Density, DIN 51757 (4) & $1100 \mathrm{~kg} \mathrm{~m}^{-3}$ at $20^{\circ} \mathrm{C}$ \\
\hline Danger of explosion & $\begin{array}{c}\text { Product does not present an explosion } \\
\text { hazard }\end{array}$ \\
\hline Biodegradability & $\begin{array}{c}\text { Aerobic degradation: }>60 \% \text { in } 28 \text { days } \\
\text { according to OECD guidelines }\end{array}$ \\
\hline Mobility & Partly water miscible \\
\hline Fish toxicity & $\begin{array}{l}\text { Bluegill: LC50 (96 hours) } 90 \mathrm{mg} \mathrm{L}^{-1} \\
\text { according to OECD } 203\end{array}$ \\
\hline Classified & $\begin{array}{l}\text { No explosive risk, non-hazardous, } \\
\text { biodegradable, low toxicity }\end{array}$ \\
\hline
\end{tabular}

*No observed effect concentration; ${ }^{\text {T}}$ The Convention for the Protection of the Marine Environment of the North-East Atlantic.
Table 3. Data for ESTISOL ${ }^{\mathrm{TM}}$ 165: aliphatic carboxylic acid ester

\begin{tabular}{|c|c|c|c|c|c|}
\hline \multicolumn{2}{|c|}{ ESTISOL ${ }^{\mathrm{TM}} 140$ batch I } & \multicolumn{2}{|c|}{ ESTISOL $^{\mathrm{TM}} 140$ batch II } & \multicolumn{2}{|c|}{ ESTISOL TM 165} \\
\hline Density & Temperature & Density & Temperature & Density & emperature \\
\hline $\mathrm{kg} \mathrm{m}^{-3}$ & ${ }^{\circ} \mathrm{C}$ & $\mathrm{kg} \mathrm{m}^{-3}$ & ${ }^{\circ} \mathrm{C}$ & $\mathrm{kg} \mathrm{m}^{-3}$ & ${ }^{\circ} \mathrm{C}$ \\
\hline 872 & 22.3 & 870 & 22.0 & 1096 & 22.1 \\
\hline 901 & -10.9 & 900 & $-11.2^{\circ} \mathrm{C}$ & 1141 & -11.6 \\
\hline 912 & -26.1 & 914 & $-29.3^{\circ} \mathrm{C}$ & 1154 & -24.3 \\
\hline 923 & -42.3 & 919 & $-36.8^{\circ} \mathrm{C}$ & 1170 & -37.9 \\
\hline 929 & -50.0 & 924 & $-42.3^{\circ} \mathrm{C}$ & 1184 & -53.7 \\
\hline 941 & -66.5 & 940 & $-63.1^{\circ} \mathrm{C}$ & 1194 & -63.4 \\
\hline 945 & -72.2 & 944 & $-68.2^{\circ} \mathrm{C}$ & & \\
\hline
\end{tabular}
manufactured by ESTI Chem A/S, Denmark

Table 4. Density characteristics for the two candidate liquids at various temperatures 


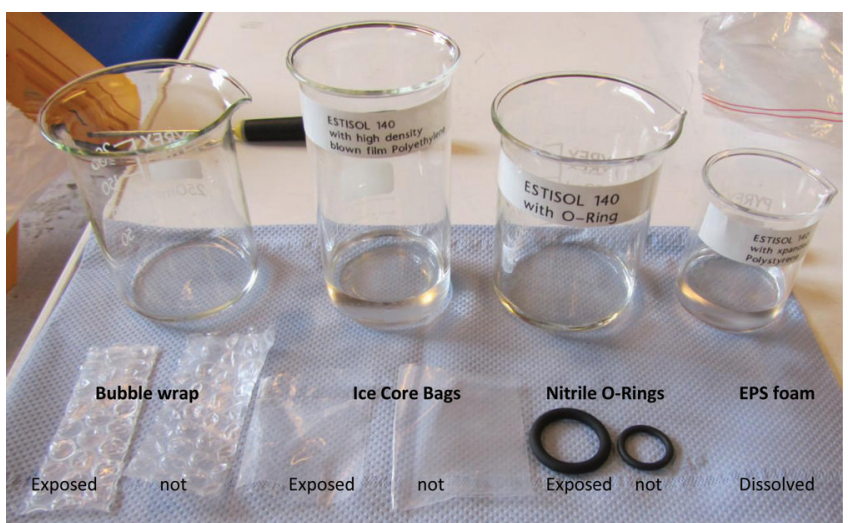

Fig. 3. A selection of the materials tested by immersion compared with no immersion.

were suspended for some time, drifting only very slowly to the lower section of the container. With pure ESTISOL ${ }^{\mathrm{TM}}$ 165 the ice granules floated rapidly to the upper area of the container. With the ESTISOL ${ }^{\text {TM }}$ 140/ESTISOL ${ }^{\text {TM }} 165$ mixture the majority of the ice had formed in the upper area within $\sim 1$ min, forming a stable well-defined visible separation of ice chips and drill liquid. The process was repeated, with similar observations. The mixtures were left for several days without any noticeable change and were subsequently left for a total of 2 years without any noticeable change to the separated ice and drill liquid, or any visible dissolving of ice.

The test procedures were repeated with a second batch of samples in the $-25^{\circ} \mathrm{C}$ freezer. The observations from the tests carried out at $-25^{\circ} \mathrm{C}$ were very similar to the tests performed at $-16^{\circ} \mathrm{C}$ with the exception that the mixture of pure ESTISOL ${ }^{\mathrm{TM}} 140$ with ice separated very slowly; the ice was almost suspended. These mixtures were left for a total of 2 years without any noticeable change to the separated ice and drill liquid, or any visible dissolving of ice.

Further tests were carried out in a chest freezer at $-55^{\circ} \mathrm{C}$, similar to the tests performed at $-16^{\circ} \mathrm{C}$ and $-25^{\circ} \mathrm{C}$. For all the mixtures in these tests the ice granules were observed to float to the surface of the containers.

\section{MATERIAL TESTS}

The two candidate drill liquids were tested with various materials that are normally used in ice-core drilling projects or are considered likely to come into contact with drill liquids in future projects. Some of the tests were 'very noticeable',

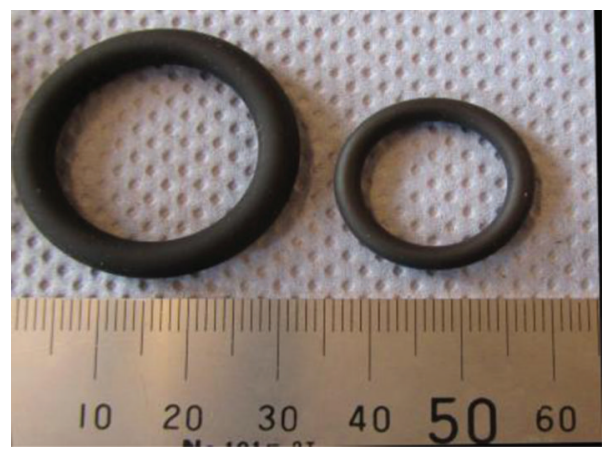

Fig. 4. O-ring after immersion for 2 days (right); O-ring with no immersion (left).
Table 5. Key values of dynamic and kinematic viscosity at room temperature to $-66^{\circ} \mathrm{C}$

\begin{tabular}{lccccc}
\hline \multicolumn{3}{c}{ ESTISOL ${ }^{\mathrm{TM}} 140$} & \multicolumn{4}{c}{ ESTISOL $^{\mathrm{TM}} 165$} \\
Temperature & Density & Viscosity & Temperature & Density & Viscosity \\
${ }^{\circ} \mathrm{C}$ & $\mathrm{kg} \mathrm{m}^{-3}$ & $\mathrm{~mm}^{2} \mathrm{~s}^{-1}$ & ${ }^{\circ} \mathrm{C}$ & $\mathrm{kg} \mathrm{m}^{-3}$ & $\mathrm{~mm}^{2} \mathrm{~s}^{-1}$ \\
\hline & & & & & \\
\hline-10.8 & 898 & 3.0 & -9.2 & 1139 & 5.8 \\
-29.8 & 914 & 5.0 & -18.9 & 1149 & 9.1 \\
-39.3 & 921 & 8.2 & -35.5 & 1165 & 23.5 \\
-49.3 & 930 & 22 & -40.8 & 1171 & 36 \\
-57.4 & 936 & 53 & -46.1 & 1176 & 77 \\
-66.1 & 943 & 117 & & & \\
\hline
\end{tabular}

such as when the liquids come into contact with expanded polystyrene foam (EPS foam), which rapidly dissolved. Most materials showed either no effect or very small effects only days later, such as nitrile rubber O-rings (Fig. 3).

\section{No noticeable effects}

High-density blown film polyethylene (ice-core bags)

Polyethylene film (bubble wrap)

Polypropylene (PP)

Polytetrafluoroethylene (PTFE/Teflon)

Polyesters (in fabrics, bottles, screens, etc.)

Rigid polystyrene

Water and ice - hydrophobic/non-polar

Wood, paper, cardboard, paper packaging

Metals ( $\mathrm{Al}, \mathrm{Fe}, \mathrm{Ti}, \mathrm{Cr}, \mathrm{Au})$

\section{Partially affected}

Polyvinyl chloride (PVC): softened and expanded over 1-2 days

Nitrile rubber O-rings (NBR, HNBR, HSN): expanded during 2 days of immersion, then contracted to approximately original dimensions and physical properties within $\sim 7$ days (Figs 4 and 5)

Softened plastics (shoe soles, gloves, aprons): certain examples expanded, lost physical integrity and eventually broke up within 1-7 days with normal operational stresses; certain boot soles appeared completely unaffected (Fig. 6)

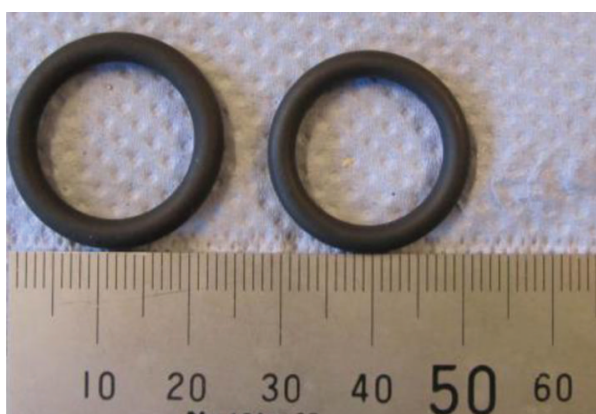

Fig. 5. O-ring returns to approximately original dimensions after 7 days at room temperature (right); O-ring with no immersion (left). 


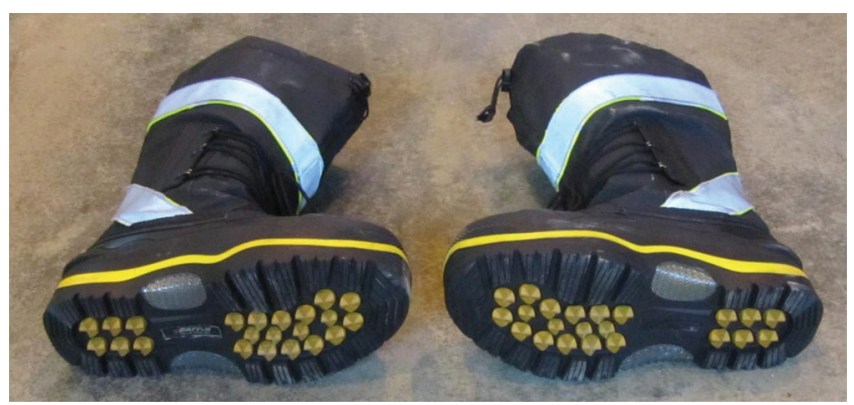

Fig. 6. No noticeable effect on boot soles after 2 weeks of exposure to ESTISOL ${ }^{\text {TM }} 140$ at $A B N$.

\section{Affected}

EPS foam: dissolved within seconds

The effects on EPS are of particular interest to the ice-core community as some types of ice-core box used for storing and transporting ice cores are made of EPS. After experiencing similar effects using ESTISOL ${ }^{\text {TM }} 240$ at Flade Isblink in 2006, we changed the composition of the Danish ice-core boxes to expanded polypropylene (EPP). These ice-core boxes were tested and appeared to show no degrading effects.

\section{FURTHER USEFUL OBSERVATIONS AND LABORATORY TESTS}

ESTISOL ${ }^{\text {TM }} 140$ and ESTISOL ${ }^{\text {TM }} 165$ are both clear, optically transparent liquids that appear suitable for video-logging the borehole using the visible spectrum. No electrical breakdown could be detected at up to $3000 \mathrm{~V} \mathrm{~cm}^{-1}$. No adverse reaction with glycol or ethanol was observed. There is an odour at $22^{\circ} \mathrm{C}$, which is less apparent at $-25^{\circ} \mathrm{C}$. The liquids have a low surface tension and show good wetting properties.

\section{FIELD TESTS: DRILLING AT NEEM 2012}

In May and June 2012 we set up a test drilling operation at NEEM camp on the northwestern Greenland ice sheet $\left(77.45^{\circ} \mathrm{N}, 51.06^{\circ} \mathrm{W}, 2481 \mathrm{~m}\right.$ altitude). A complete 4 in $(\sim 98 \mathrm{~mm})$ diameter ice core was drilled using the Hans Tausen (HT) drill, initially in dry mode to a depth of $103 \mathrm{~m}$ and then a further $28 \mathrm{~m}$ in wet mode using ESTISOL ${ }^{\mathrm{TM}} 140$. At this depth the mean average temperature of the ice is $-29^{\circ} \mathrm{C}$, implying that the kinematic viscosity of the ESTISOL TM 140 will be $3 \pm 1 \mathrm{~mm}^{2} \mathrm{~s}^{-1}$.

During the whole field test operation a borehole diameter of $126 \mathrm{~mm}$ was used to test the new drill liquid. This is smaller than a normal Danish HT drilling operation, where a borehole diameter of $129.6 \mathrm{~mm}$ is produced. Therefore, NEEM 2012 gave us a worst-case scenario to measure ascent and descent speeds. It also allowed us to compare with measurements taken using ESTISOL ${ }^{\mathrm{TM}} 240$ at Flade Isblink in 2006 (Sheldon and others, 2014). Apart from this, the HT drill configuration was unchanged.

\section{Ice cores}

Within 8 days of drilling in both dry and wet modes, the tests were concluded at a depth of $131 \mathrm{~m}$. When the ice cores were removed from the drill they were wiped dry using paper towels, similar to our previous operations at Flade

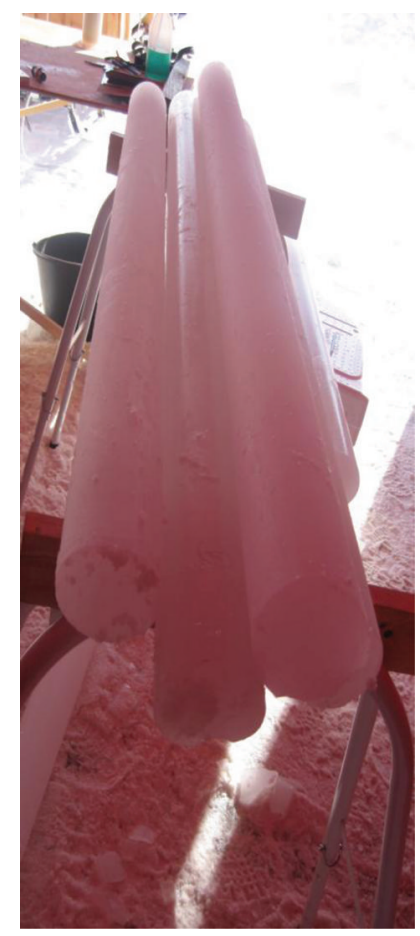

Fig. 7. First ice cores to be drilled using ESTISOL ${ }^{\mathrm{TM}} 140$ giving consistently good-quality ice cores.

Isblink (2006) and NEEM (2009-10 and 2011) (Fig. 7). This removed most of the excess liquid still on the ice-core surface. The cores were then analysed using the dielectric profiling (DEP) method before packing into ice-core boxes for shipping to Copenhagen, Denmark. In Copenhagen a very slight insignificant odour could be discerned during the unpacking. No discernible odour was noticed during electrical conductivity measurement (ECM) analysis of the ice core. Generally, we can report that ESTISOL ${ }^{\mathrm{TM}} 140$ acted as a good drill liquid, eliminating lateral fractures, producing consistently excellent quality ice core and functioning well as an intermediate-depth drill liquid.

\section{Drill handling}

Our experience of handling the drill covered with ESTI$\mathrm{SOL}^{\mathrm{TM}} 140$ at $-29^{\circ} \mathrm{C}$ is similar to that with previous drill liquids. To reduce discomfort for the drill operator, liquidresistant apparel is a necessity. Using this liquid allowed clothing to be easily dried in a well-ventilated space at $35^{\circ} \mathrm{C}$. With surface air temperatures ranging from $-10^{\circ} \mathrm{C}$ to $-25^{\circ} \mathrm{C}$, a noticeable odour similar to fly repellent could be detected. To reduce this, we recommend use of good ventilation within all drilling, core-logging, ice-core-handling and clothes-drying areas.

\section{Ice-cutting chips}

From our experience an important factor in a successful icecore drilling operation is the size and consistency of the icecutting chips. With a low-viscosity drill liquid, chips that are either too fine or too large will not be transported into the drill's chip chamber and will lead to clogging of the drill's internal chip transport cavity between the core barrel and the outer core barrel. This can lead to reduced ice-core run lengths, lost chips in the borehole and generally bad chip recovery. Using our HT drill with a 'normal' set-up pitch of $4.0 \mathrm{~mm}$ with ESTISOL ${ }^{\mathrm{TM}} 140$ produced ice chips with 'good' 


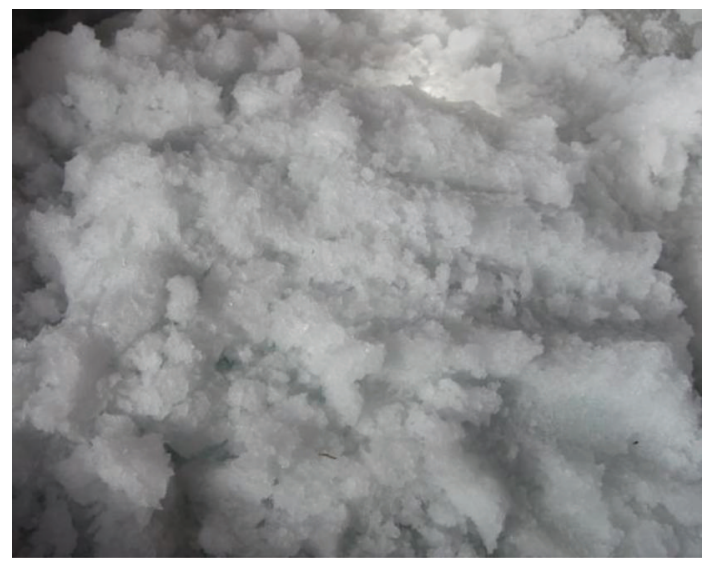

Fig. 8. Drill chips collected at $125 \mathrm{~m}$ : good chip size $(\sim 2-3 \mathrm{~mm})$ and recovery.

granular consistency which gave good chip transportation (Fig. 8). Ice-core lengths were an average of $1.53 \mathrm{~m}$, chips were found mainly in the chip chamber and no chips were found on the top of the core.

\section{Drill liquid/ice separation using liquid phase fractionation}

The ice-cutting chips from the HT drill chip chamber were collected (Fig. 9) and left to melt overnight in a room at $\sim 35^{\circ} \mathrm{C}$. The water and ESTISOL ${ }^{\mathrm{TM}} 140$ separated into two very clear bands: water in the lower band with $\sim 65 \%$ by volume and ESTISOL ${ }^{\mathrm{TM}} 140$ in the upper remaining band. The mixture was then left outside to cool and the water to refreeze. The ESTISOL 140 could then be easily and effectively removed without the ice (Fig. 10), giving a 'proof of concept' of a liquid phase fractionating method for separating the water and drill liquid to allow the reuse of the

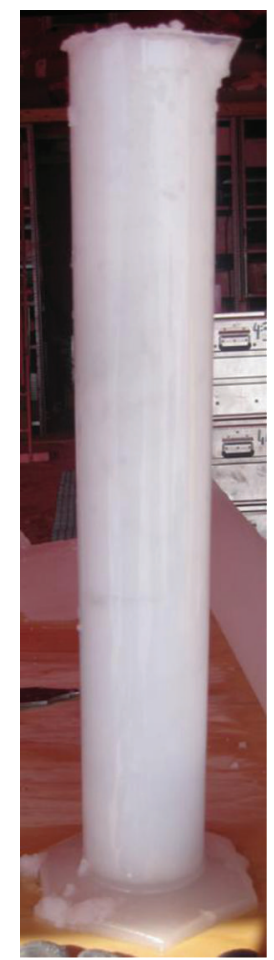

Fig. 9. Ice chips before melting.

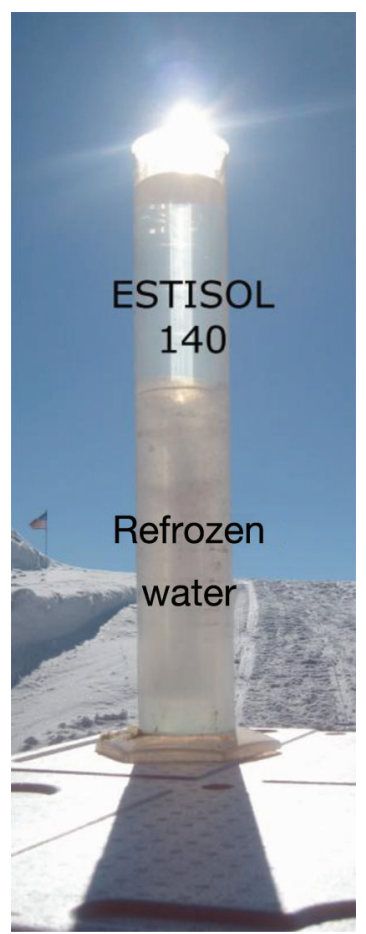

Fig. 10. Ice chips after melting and refreezing.

ESTISOL ${ }^{\mathrm{TM}}$ 140. The refrozen water was then allowed to melt again. Only a thin film of drill liquid could be seen, $\sim 1 \%$ or less by volume. From our experience this compares with $\sim 7-10 \%$ loss when using the more traditional 'centrifuge method' used at NorthGRIP and NEEM.

\section{Measured drill ascent and descent speeds}

In a $126 \mathrm{~mm}$ diameter borehole the drill descent speed was $\sim 1.0 \mathrm{~m} \mathrm{~s}^{-1}$ and the ascent speed was $\sim 0.8 \mathrm{~m} \mathrm{~s}^{-1}$ (full drill with $\sim 2500 \mathrm{~N}$ tension).

The low kinematic viscosity of ESTISOL ${ }^{\text {TM }} 140$ ensured relatively fast transit times for the drill and reduced system stresses during the hoisting procedure. Drill descent speeds of $1.0 \mathrm{~m} \mathrm{~s}^{-1}$ were achieved within the $126 \mathrm{~mm}$ diameter borehole at temperatures of $-29^{\circ} \mathrm{C}$, implying a drill liquid kinematic viscosity of $3 \pm 1 \mathrm{~mm}^{2} \mathrm{~s}^{-1}$. This is $30 \%$ faster than the speed $\left(0.7 \mathrm{~m} \mathrm{~s}^{-1}\right)$ achieved with a similar HT drill set-up using ESTISOL ${ }^{\mathrm{TM}} 240$ at a higher temperature of $-15.7^{\circ} \mathrm{C}$ with a kinematic viscosity of $13.5 \pm 1 \mathrm{~mm}^{2} \mathrm{~s}^{-1}$.

\section{Summary of NEEM 2012 field tests}

Drilling and recovery of ice core went well and without issues.

Recovered consistently excellent quality ice cores

No problems were encountered cleaning the ice cores. As with our previous experience with other drill liquids, we recommend thorough cleaning of the ice cores in the field before packing

Recovery of liquid from the chips is very good

Excess liquid splashed on the driller's clothing, boots and gloves dried readily at $35^{\circ} \mathrm{C}$

With surface temperatures of $-10^{\circ} \mathrm{C}$ to $-25^{\circ} \mathrm{C}$ a noticeable odour similar to fly repellent could be discerned; 


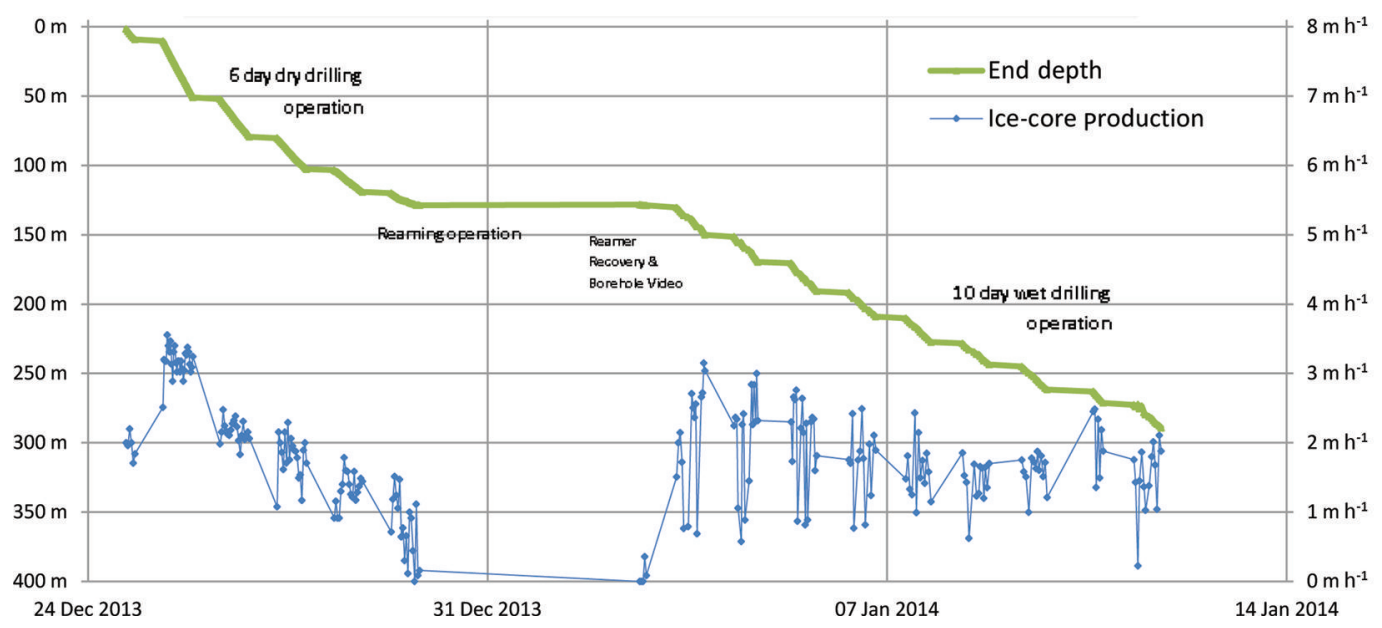

Fig. 11. Depth drilled and rate of ice core drilled at ABN 2013/14. Drilling commenced on day 5 after arrival and finished 20 days later at a depth of $303 \mathrm{~m}$, with an approximate ice-core age of 2-2.5 ka. Of the total ice core, the first $131 \mathrm{~m}$ were recovered in 5.5 days using the HT drill in a 'dry'-mode set-up, followed by a reaming process, with the final $172 \mathrm{~m}$ in the 'wet'-mode set-up using ESTISOL 140 as drill liquid. Drill performance during both drilling stages and the retrieved ice-core quality were excellent at ice temperatures ranging from $-43.5^{\circ} \mathrm{C}$ to $-45.5^{\circ} \mathrm{C}$ and surface air temperatures ranging from $-4^{\circ} \mathrm{C}$ to $-25^{\circ} \mathrm{C}$ during the drilling operation.

therefore, at these temperatures, ventilation is recommended

Drill descent speeds of $1.0 \mathrm{~m} \mathrm{~s}^{-1}$ were achieved at temperatures of $-29^{\circ} \mathrm{C}, 30 \%$ faster than using ESTISOL ${ }^{\mathrm{TM}}$ 240 at $-15.7^{\circ} \mathrm{C}$

ESTISOL ${ }^{\mathrm{TM}} 140$ appears to be a candidate for drilling operations at ice temperatures well below $-29^{\circ} \mathrm{C}$

\section{AURORA BASIN NORTH (ABN) PROJECT 2013/14}

In late December 2013 the Danish intermediate-depth drilling system was set up at Aurora Basin $\left(71^{\circ} 10.1^{\prime} \mathrm{S}\right.$, $111^{\circ} 23.8^{\prime} \mathrm{E}_{;}, \sim 2700 \mathrm{ma}$ a.s.l.) on the East Antarctic high plateau $\sim 525 \mathrm{~km}$ from the Australian coastal base (Casey station).

Initially we drilled to $131 \mathrm{~m}$ in dry drilling mode using our standard $126 \mathrm{~mm}$ diameter 'dry' drill head, followed by reaming the borehole to $135 \mathrm{~mm}$ diameter using our standard No. 1 reamer. The reaming process allowed our standard $129.6 \mathrm{~mm}$ diameter 'wet' drill head to be lowered into the borehole. A $200 \mathrm{~L}$ drum of ESTISOL ${ }^{\mathrm{TM}} 140$ was poured into the lower portion of the borehole using a $90 \mathrm{~m}$ long fire hose. The $200 \mathrm{~L}$ of ESTISOL ${ }^{\mathrm{TM}} 140$ gives a liquid column height of $\sim 14 \mathrm{~m}$ within the $135 \mathrm{~mm}$ diameter reamed borehole. The HT drill was then lowered to the base of the borehole. At the borehole base the $5 \mathrm{~m}$ long drill was completely submerged in the ESTISOL ${ }^{\mathrm{TM}} 140$ causing the liquid column height to increase by $1.5 \mathrm{~m}$ due to the displacement by the drill's closed volume. Drilling started and immediately the drill performed very well, producing successive ice cores of consistently excellent quality. When removed from the drill the ice cores were wiped dry using paper towels before the logging process. The cores were then stored in cold open ice-core storage buffer for $\sim 1$ day before being packed ready for shipping to Hobart, Australia. In the storage and processing freezers in Hobart no odour could be detected from the ESTISOL ${ }^{\mathrm{TM}}$ 140, when opening the boxes. A faint odour was discernible when putting one's nose inside the ice-core bags (personal communication from M. Curran, 2014). Similar to our previous experience with other drill liquids, we recommend thorough cleaning of the ice cores in the field before packing.

The 'wet'-mode drilling operation progressed without incident for the following 10 days until the primary scientific goal, the recovery of a continuous $2 \mathrm{ka}$ ice-core record, had been reached and exceeded. The average daily production with a single two-operator shift was $17 \mathrm{~m} \mathrm{~d}^{-1}$, with an average ice-core length of $1.27 \mathrm{~m}$ per run (Fig. 11). The ice temperature ranged from $-43.5^{\circ} \mathrm{C}$ at a depth of $10 \mathrm{~m}$ to $-45.5^{\circ} \mathrm{C}$ at $303 \mathrm{~m}$, implying from our measurements that the ESTISOL ${ }^{\text {TM }} 140$ had a kinematic viscosity of $6 \pm 2 \mathrm{~mm}^{2} \mathrm{~s}^{-1}$ and a density of $925 \pm 2 \mathrm{~kg} \mathrm{~m}^{-3}$.

The drill descent and ascent speeds were measured in the $129.6 \mathrm{~mm}$ diameter borehole and were regularly $0.8-$ $1.0 \mathrm{~m} \mathrm{~s}^{-1}$ without reaching the drill's terminal descent velocity or causing excessive stresses during the hoisting process.

In the manufacturer's most recent material safety datasheet, ESTISOL ${ }^{\mathrm{TM}} 140$ has been reclassified as a skin irritant (irritant to skin and mucous membranes). No skin irritation was observed during the $\mathrm{ABN}$ project; however, we do recommend that splashproof apparel is worn by all drill operators.

\section{Drilling performance at $\mathrm{ABN}$}

Systematic investigation into ice-core quality

During the drilling operation the recovery of high-quality ice core was a prime objective and to this end a systematic quality control was put in place. This involved (1) checks for possible missing core using ice-core break matching techniques during logging and comparing drill depth with logging depth for any unexplained differences, (2) visual checks for external cracks, scratches or damage and (3) visual checks for internal fractures and cracks.

From previous experience of using a drill liquid at sites where melt layers are minimal, very small internal cracks can develop at depths of $200 \mathrm{~m}$ and below if the liquid column is not high enough (Popp and Hansen, unpublished information). At $\mathrm{ABN}$ we measured the liquid column height with each drilling run and gave attention to whether any very small internal fractures were starting to develop in the ice core. When small fractures started to appear, the liquid 


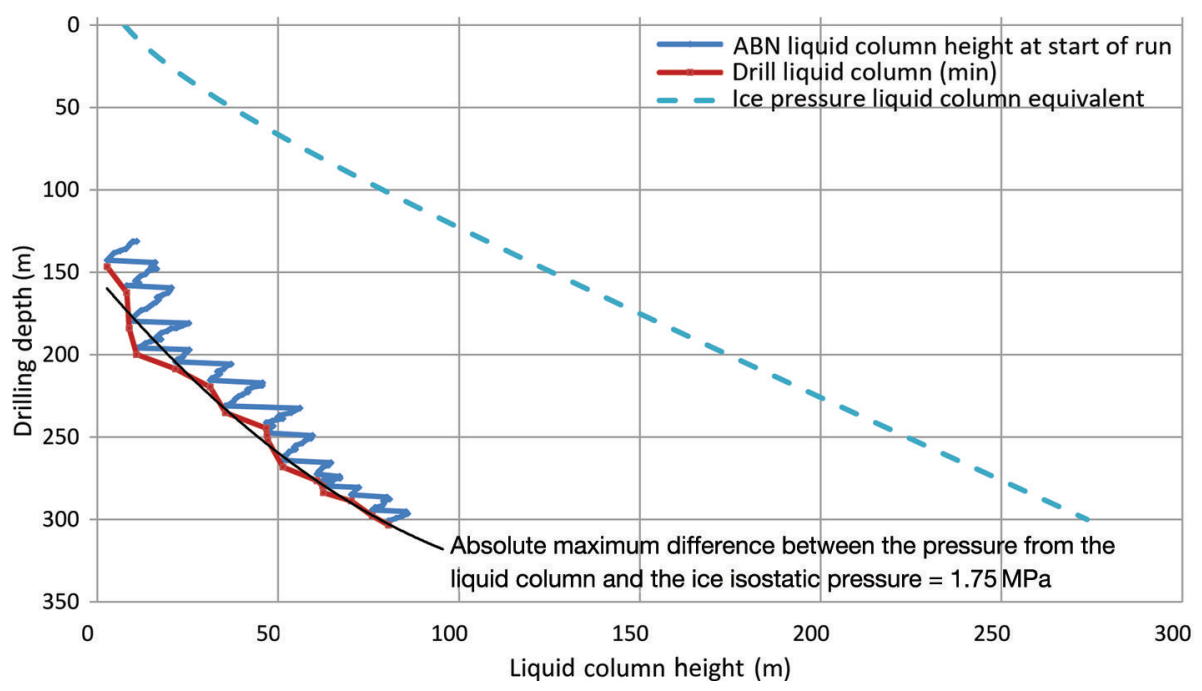

Fig. 12. Systematic ice-core quality control. Red line indicates the absolute minimum liquid column height at a given drill depth. Dashed blue line indicates the liquid column height equivalent of the calculated ice isostatic pressure.

column was immediately increased in height by pouring more ESTISOL ${ }^{\text {TM }} 140$ into the borehole. From this work we quantified the absolute minimum liquid column required to preserve the recovery of good-quality ice core. Later, we compared these data to the calculated isostatic pressure of the ice (Fig. 12). We found that if the difference between the hydrostatic pressure exerted by the drill liquid column and the ice isostatic pressure was $>1.75 \mathrm{MPa}$, very small internal fractures would start to occur.

We extrapolated these data and so calculated the liquid column height required to retain high ice-core quality at greater depth. We estimated that the liquid level (i.e. the depth from the present-day snow surface to the top of the liquid column) should ideally be kept at $164 \mathrm{~m}$; it should not be allowed to fall below $220 \mathrm{~m}$ (Fig. 13).

From this extrapolation we estimated the total drill liquid requirement for a given future project. Assuming 25\% loss of drill liquid (past experience shows $\sim 16 \%$ loss), Table 6 shows the calculated quantities of drill liquid to drill to $\geq 500 \mathrm{~m}$.

\section{Drill liquid recovery}

An essential procedure of a drilling operation is the efficient recovery and subsequent reuse of the drill liquid brought up to the surface inside the drill. With each run many litres of drill liquid are pulled out of the borehole as either almost pure liquid trapped in the closed spaces inside the drill or as a chip mixture of the ice cuttings and drill liquid. During the NEEM 2012 field tests, $~ 35 \%$ of the chip mixture was found to be ESTISOL ${ }^{\mathrm{TM}}$ 140, representing $2 \mathrm{~L}$ of drill liquid per metre of ice core recovered. A further $5.5 \mathrm{~L}$ of drill liquid per metre of ice core was found inside the drill. This amount of drill liquid ( $7.5 \mathrm{~L}$ per meter of recovered ice core) represents a possible loss of $1000 \mathrm{~L}(5 \times 200 \mathrm{~L}$ drums $)$ for every $133 \mathrm{~m}$ of ice core drilled.

Instead of employing a traditional centrifuge system, which normally weighs $>150 \mathrm{~kg}$ and is not as efficient at liquid retrieval, at $A B N$ we planned to use a liquid phase fractionating method to separate the ice from the drill liquid, similar to the concept tested at NEEM in 2012. We built a system consisting of a $200 \mathrm{~L}$ drum mounted

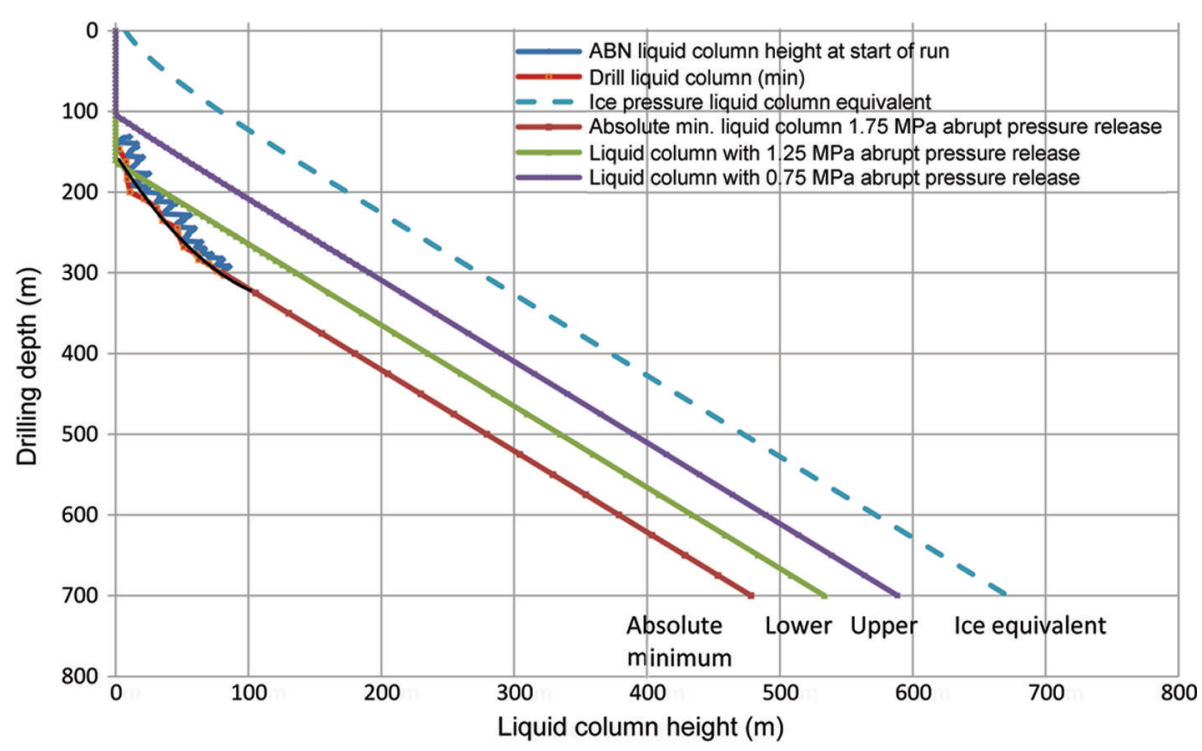

Fig. 13. Estimates of the drill liquid column height required to ensure good ice-core quality. 
Table 6. Calculated quantities of drill liquid required for a $129.6 \mathrm{~mm}$ diameter borehole to retain good ice-core quality for various intermediate-depth drilling projects

\begin{tabular}{|c|c|c|c|}
\hline $\begin{array}{l}\text { Drill } \\
\text { depth }\end{array}$ & Absolute minimum & $\begin{array}{l}\text { Lower } \\
\text { recommendation }\end{array}$ & $\begin{array}{c}\text { Upper } \\
\text { recommendation }\end{array}$ \\
\hline
\end{tabular}

\begin{tabular}{llll}
\hline 500 & 23 drums & 28 drums & 32 drums \\
600 & 31 drums & 36 drums & 40 drums \\
700 & 40 drums & 44 drums & 49 drums \\
\hline
\end{tabular}

horizontally with two $1.5 \mathrm{~kW}$ drum heaters surrounded by insulation padding. An opening was made on the upper portion of the drum to allow the mixture to be poured in. A tap was added to the lower part of the drum to allow the liquids to be removed from the drum, first water followed by ESTISOL ${ }^{\mathrm{TM}} 140$.

During the whole drilling operation, $1900 \mathrm{~L}$ of fresh pure ESTISOL ${ }^{\text {TM }} 140$ was poured into the borehole. Using the liquid phase fractionating method $\sim 1266 \mathrm{~L}$ was recovered from the chips and slush brought to the surface by the drill. Of this amount, $\sim 766 \mathrm{~L}$ was poured back into the borehole and $500 \mathrm{~L}$ left over on the surface (Table 7).

\section{FUTURE APPLICATIONS}

There have been several project proposals for which ESTISOL ${ }^{T M} 140$ is being considered. It will be used at our next intermediate-depth drilling project, a $\sim 660 \mathrm{~m}$ ice core at Renland ice cap, eastern Greenland, in 2015. It is also a possible candidate drill liquid with ESTISOL ${ }^{\mathrm{TM}} 165$ for use at our next deep drilling project, the proposed $2500 \mathrm{~m}$ ice core EastGRIP project, on the northeastern Greenland ice sheet, possibly starting in 2016.

\section{CONCLUSION}

In 2011, after being introduced by EstiChem A/S, two new drill liquid candidates were investigated: the aliphatic synthetic ester ESTISOL ${ }^{\mathrm{TM}} 140$ and the aliphatic carboxylic acid ester ESTISOL TM 165. In the manufacturer's data and from our own laboratory tests and observations, the two candidate liquids showed many desirable physical, chemical and biological properties.

Compared with drill liquids used previously, these new candidates have some distinct overall advantages. These include the ability to fine-tune the density to the desirable range $\left(910-950 \mathrm{~kg} \mathrm{~m}^{-3}\right)$ for temperatures from $0^{\circ} \mathrm{C}$ to $-60^{\circ} \mathrm{C}$, useful low-viscosity temperature characteristics over a range $0^{\circ} \mathrm{C}$ to $-54^{\circ} \mathrm{C}$, beneficial low environmental impact status, better health and safety specifications and simplification of logistical transport due to non-hazardous classification. We found some undesirable properties, such as some small physical degradation effects on certain soft expanded plastics and rubbers, and the odour of the evaporated liquid. These are either insignificant or easily mitigated and, compared with previous drill liquids, these undesirable properties are considerably less evident. Similar to our previous experience with other drill liquids, we recommend thorough cleaning of the ice cores using paper

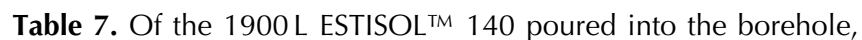
$>1615 \mathrm{~L}$ was left over within the borehole or on the surface. Approximately $15 \%$ of the drill liquid was unaccounted for during the operation, probably due to a combination of seepage into the firn during the hoisting process, small surface spillages and errors in our measurements

Drill liquid poured into the borehole

$\begin{array}{lc}\text { Fresh pure ESTISOL } & 1900 \mathrm{~L} \\ \text { Recycled ESTISOL } 140 & 760\end{array}$

Estimated drill liquid left over

\section{In borehole}

$1115 \mathrm{~L}$

(84.5 m liquid column height)

Recycled but unused

$500 \mathrm{~L}$

Estimated drill liquid loss

$15 \%$

towels before packing, and good ventilation in areas where the liquid is present.

We can report on the successful use of ESTISOL ${ }^{\text {TM }} 140$ at NEEM in 2012. At NEEM, where the average ice temperature is $-29^{\circ} \mathrm{C}$, testing of ESTISOL ${ }^{\mathrm{TM}} 140$ demonstrated that it could be used in the 'warm' conditions found on the Greenland ice sheet.

We can also report successful use of ESTISOL ${ }^{\mathrm{TM}} 140$ as an intermediate-depth drill liquid at ABN in 2013/14. This icecore drilling operation was successfully concluded within 3 weeks, with the recovery of a continuous $2-2.5 \mathrm{ka}$ icecore record to a depth of $303 \mathrm{~m}$. The quality of the ice core retrieved and drill performance were excellent at ice temperatures ranging from $-43.5^{\circ} \mathrm{C}$ to $-45.5^{\circ} \mathrm{C}$, demonstrating it can be used in the ' $\mathrm{Cool}^{\prime}$ conditions found on the East Antarctic high plateau.

During both these field seasons no modifications were necessary to our normal HT drill configuration, which gave excellent performance, allowing completion of the ice-core recovery component of the projects well within the projected time.

We also report on the successful application of a liquid phase fractionating method for separating ice from ESTISOL ${ }^{\text {TM }} 140$ and on results of a systematic ice-core quality control.

\section{ACKNOWLEDGEMENTS}

We are greatly indebted to the various funding agencies for supporting the NEEM ice-core drilling projects. NEEM is directed and organized by the Center for Ice and Climate at the Niels Bohr Institute and the US National Science Foundation (NSF), Office of Polar Programs. It is supported by funding agencies and institutions in Belgium (FNRS-CFB and FWO), Canada (NRCan/GSC), China (CAS), Denmark (FIST), France (IPEV, CNRS/INSU, CEA and ANR), Germany (AWI), Iceland (Rannls), Japan (NIPR), Korea (KOPRI), The Netherlands (NWO/ALW), Sweden (VR), Switzerland (SNF), United Kingdom (NERC) and the USA (US NSF, Office of Polar Programs). We thank all contributors to the $A B N$ project for their support. We also thank EstiChem A/S for data and helpful discussions regarding the properties of the many candidate drill liquids initially tested and specifically for ESTISOL ${ }^{\text {TM }}$ 240, ESTISOL ${ }^{\text {TM }} 140$ and ESTISOL 165. 


\section{REFERENCES}

Gerasimoff M (2003) Drilling fluid observations and recommendations for US Polar Program, Waiscores Drilling Project. (Internal Report) Space Science and Engineering Center, University of Wisconsin-Madison, Madison, WI http://icedrill.org/ Documents/Download.pm?DOCUMENT_ID=50

Gundestrup NS, Clausen HB, Hansen SB and Johnsen SJ (1994) Hole liquids and gaskets for the ISTUK deep ice core drill. Mem. Natl Inst. Polar Res., Special Issue 49, 327-334

Popp TJ, Hansen SB, Sheldon SG, Schwander J and Johnson JA (2014a) Drilling into debris-rich basal ice at the bottom of the NEEM (Greenland) borehole. Ann. Glaciol., 55(68) (doi: 10.3189/2014AoG68A029) (see paper in this issue)

Popp TJ, Hansen SB, Sheldon SG and Panton C (2014b) Deep icecore drilling performance and experience at NEEM, Greenland.
Ann. Glaciol., 55(68), 53-64 (doi: 10.3189/2014AoG68A042) (see paper in this issue)

Sheldon SG, Steffensen JP, Hansen SB, Popp TJ and Johnsen SJ (2014) The investigation and experience of using ESTISOL 240 and COASOL as ice-core drilling liquids. Ann. Glaciol., 55(68) (doi: 10.3189/2014AoG68A036) (see paper in this issue)

Talalay PG and Gundestrup NS (2002) Hole fluids for deep ice core drilling. Mem. Natl Inst. Polar Res., Special Issue 56, $148-170$

Talalay P and 6 others (2014) Environmental considerations of lowtemperature drilling fluids. Ann. Glaciol., 55(65), 31-40 (doi: 10.3189/2014AoG65A226)

Vasiliev NI and Kudryashov BB (2002) Hydraulic resistance to movement of a drill suspended by a cable in a bore-hole in travels. Mem. Natl Inst. Polar Res., Special Issue 56, 142-147 